University of Wollongong

Research Online

Faculty of Social Sciences - Papers (Archive) Faculty of Arts, Social Sciences \& Humanities

2015

Therapeutic relationships in child-centered personal construct

psychotherapy: experiments in constructions of self

Deborah Truneckova

University of Wollongong, deboraht@uow.edu.au

Linda L. Viney

University of Wollongong, Iviney@uow.edu.au

Follow this and additional works at: https://ro.uow.edu.au/sspapers

Part of the Education Commons, and the Social and Behavioral Sciences Commons

Research Online is the open access institutional repository for the University of Wollongong. For further information contact the UOW Library: research-pubs@uow.edu.au 


\title{
Therapeutic relationships in child-centered personal construct psychotherapy: experiments in constructions of self
}

\author{
Abstract \\ As personal construct psychology is person-centered, child-centered personal construct psychotherapy \\ sets out to have the child the central subject for any psychological enquiry. Child-centered personal \\ construct psychotherapy is developed from the theoretical and practice-based assumptions of personal \\ construct psychology and practiced through the medium of play therapy. Effective psychological change \\ occurs when the child's self-theory is elaborated through the extension and definition of the core \\ construct self-other, with the therapist's construing of the child becoming primary evidence of how the \\ child understands self. Clinical material is provided to further illustrate our child-centered \\ psychotherapeutic approach.
}

\section{Keywords}

relationships, child, centered, personal, therapeutic, construct, self, psychotherapy, experiments, constructions

\section{Disciplines}

Education | Social and Behavioral Sciences

\section{Publication Details}

Truneckova, D. \& Viney, L. L. (2015). Therapeutic relationships in child-centered personal construct psychotherapy: experiments in constructions of self. Journal of Constructivist Psychology, 28 (3), 195-209. 
THERAPEUTIC RELATIONSHIPS IN CHILD-CENTERED PERSONAL CONSTRUCT PSYCHOTHERAPY: EXPERIMENTS IN CONSTRUCTIONS OF SELF

Deborah Truneckova

and

Linda L. Viney

University of Wollongong

Deborah Truneckova, Ph.D., Honorary Fellow, Illawarra Institute for Mental Health, Faculty of Social Science, University of Wollongong, Australia.

Linda L. Viney, Ph.D. (deceased). Professorial Research Fellow, Faculty of Social Science, University of Wollongong, Australia.

Correspondence should be addressed to: Dr Deborah Truneckova, 12 Dobbie Avenue, East Corrimal, New South Wales 2518, Australia. E-mail:dtruneck1@bigpond.com 


\begin{abstract}
As personal construct psychology is person-centered, child-centered personal construct psychotherapy sets out to have the child the central subject for any psychological enquiry. Child-centered personal construct psychotherapy is developed from the theoretical and practice-based assumptions of personal construct psychology and practised through the medium of play therapy. Effective psychological change occurs when the child's selftheory is elaborated through the extension and definition of the core construct 'self-other,' with the therapist's construing of the child becoming primary evidence of how the child understands self. Clinical material is provided to further illustrate our child-centered psychotherapeutic approach.
\end{abstract}

\title{
Key Words:
}

personal construct psychology

play therapy

child psychotherapy 


\section{THERAPEUTIC RELATIONSHIPS IN CHILD-CENTERED PERSONAL CONSTRUCT PSYCHOTHERAPY: EXPERIMENTS IN CONSTRUCTIONS OF SELF}

George Kelly (1955/1991a) asserted that personal construct psychology is person centered:"We must anchor our basic concepts in personal experience, not in the experiences he causes others to have or which he appears to seek to cause others to have” (Kelly, 1969c, p.273).Kelly also suggested that as a result of experience, individuals develop a complex of personal constructs, a network and hierarchy of discriminations. These discriminations become the means by which the person decides about the most appropriate behavior to use to meet present and future situations. Stated Kelly: "The construct refers to the nature of the distinction one attempts to make between events” (Kelly, 1970, p.13).As an act of interpretation, the process of construing enables the person to sort understandings of self as being alike and yet different from others. Contrast is central to the definition of the construct. What the person knows about his/her self is connected to a uniquely individualized system of bi-polar constructs (Raskin, 2013).Subjective experience becomes a comparison between oneself and others (Bannister \& Fransella 1986).Kelly (1955/1991a) maintained that therapists must understand that the differences "between two people has less to do with disparate events they have encountered than with the unique constructions they place upon these events” (R. A. Neimeyer\& G. J. Neimeyer, 1987, p. 14).Child-centered personal construct psychotherapy is focused on the child's unique personal meanings where all experiences including "emotional experiences (of the child) are defined from the perspective of the experiencer rather than the recipient” (Chiari, 2013, p. 252).

In the following paper we provide nine assumptions behind our approach to childcentered personal construct psychotherapy. These assumptions rest on the position that interpersonal relationships are a central motivational force in human development. The nine assumptions are: 
1. Constructions of interpersonal relationships begin in infancy and develop through the relationship between child and mother (primary caregiver).

2. How children construe their first interpersonal relationships influences how they approach and respond to future relationships.

3. Psychological problems develop when infants and parents misunderstand each other and fail to form a role relationship.

4. Conceptualization of children's psychological problems is centered on constructive alternativism.

5. Behavior carries its own unique sense for children and is central to understanding their construing of self-other.

6. The establishment of the therapeutic relationship is central to the practice of childcentered personal construct psychotherapy.

7. Within the therapeutic relationship the psychological problems of children are the events and experiences to be reconstrued before core construing.

8. As children encounter their world experientially, therapeutic change will often occur experientially.

9. Play therapy facilitates the communication of experiential constructions.

In setting out to translate these assumptions into psychotherapeutic practice, we discuss how children develop an understanding of self and how children come to experience psychological problems. The paper also addresses how child-centered personal construct psychotherapy conceptualizes psychological problems and employs a therapeutic approach to respond to them.

To assist in illustrating these practices, clinical material is provided from the psychotherapy sessions of a client, 10-year-old John. Referred by his school and foster mother, John began child-centered personal construct psychotherapy three years ago and 
continues weekly (50 minutes).John and his family gave informed consent and any identifying details are amended to protect John and his family's confidentiality. For much of his time at school and home, John was described as being out of control; he was violent towards people and property. This behavior contributed to past failed foster placements until his current foster placement of four years. For the first three years of his life, John experienced general neglect resulting in malnutrition, as well as dirty and unhygienic living conditions. The child protection authorities investigated and discovered evidence of physical and emotional violence toward John. It was also determined that John’s body was scarred by a number of old and new cigarette burns and John was self-harming by sticking pins and other objects into his body. At this time, John who was three years old, along with his twin sisters one year old, were removed from parental care and placed in government care. Subsequent to these judicial actions, John's father was charged with multiple acts of sexual abuse of John. John does not have contact with his sisters and biological parents. When he was enrolled at school, he was diagnosed with a moderate intellectual disability along with attention deficit hyperactivity disorder, oppositional defiant disorder, and sleep problems. He was placed in a smaller class with a teacher trained to teach students with learning and behavior disorders. Currently, his levels of impulsivity and defiance at school have decreased both in terms of frequency and intensity. At home, the destruction of property and violence against others has also decreased, with John now referring to his current caregiver as his mother. While his sleeping has improved, he continues to be unduly anxious at night. Within the classroom, John is able to focus and concentrate, completing assigned tasks.He trusts and respects his teacher and generally now wants to please her. However, he continues to experience conflicting relationships with his peers.

\section{Constructions of Interpersonal Relationships Begin in Infancy and Develop Through the Relationship between Child and Mother (primary caregiver)}


Interpersonal relationships are the cornerstone of personal construct psychotherapy. The current interest by psychotherapists in attachment theory mobilizes and engages the considerable contribution personal construct psychology can make to the psychological understanding of infant/child and mother/caregiver relationships.

First proposed by John Bowlby (1973, 1980, 1982, 1998) and later expanded by Mary Main (Main \& Solomon, 1986) and Mary Ainsworth (Ainsworth, Blehar, Waters,\& Wall, 1978), attachment theory attempts to explain how a relationship with a caregiver impacts a child's self-theory. It also describes the impact the child's early relational experience with his/her primary caregiver has on the way the child approaches later relationships and how this experience influences the child's social, emotional and cognitive development. Early attachment relationships provide an internal working model for relationships, which influences how the child responds interpersonally in later relationships. Although later experiences may influence and modify the model of relationship formation the child remains strongly guided by these early attachment experiences.

Personal construct psychology describes how early in life the baby elaborates his/her construct systems while in relationship with another. It is in and through this caring relationship with another that the baby begins to use constructs. The other/the mother interprets the baby's needs through her construct system, which provides the baby with the means by which to communicate present and future needs. Both the mother and the baby are posing questions about each other and the outside world, carrying out behavioral experiments and evaluating their outcomes in terms of satisfying basic needs. Mother and baby are attempting to construe each other's construction processes, each working out what the other 'is about.' They are both creating meaning in order to anticipate their present and future needs. In this account, a secure attachment relationship develops as the mother, along with the baby, begins to build interpretative frameworks in which the baby's needs, level of 
satisfaction, and pleasure are meaningfully understood by both the mother and baby. This construing of self-other by both mother and baby occurs as the two are being held in a role relationship. Within the role relationship, the mother provides the 'road map' for the baby to anticipate the world and to have basic needs satisfied. Both behavioral and emotional expressions provide the validation needed for both mother and baby to remain attuned to each other. The baby tests the responsiveness of the relationship and the validity of the consequent actions is assessed through the baby's behavior and the mother's response. Through their caring relationship both the mother and baby acquire "the constructions through which the other construes reality” (Sassaroli\& Lorenzini, 1992, p. 240).The baby’s emotional response indicates whether his/her experiment has been successful and satisfactory.

The most crucial personal relationship for the child is the first relationship with the child's primary caregiver. This caring mother or person sets the foundation for the child's construing, no matter how much the child may later elaborate his/her own view (Salmon, 1970, p. 216).Salmon (1970) understands these primary interactions between mother and child in terms of personal construct theory's commonality and sociality corollaries(Kelly, 1955/1991a, 1955/1991b).The commonality corollary states: “To the extent that one person employs a construction of experience which is similar to that employed by another his/her psychological processes are similar to those of the other person” (Kelly, 1955/1991a, p. 63).In the relationship, the mother offers a construction of experience that includes constructions of parenting, which are also shared by the broader community. The mother "helps to define the relevancies of situational contexts for the child thereby offering (the child) a construction in terms of which (the child) can act towards the situation” (Salmon, 1970, p. 206).This provides the child with the construct systems (i.e., "the common language”) necessary for the child to begin relating to others. 
The sociality corollary is also crucial in understanding the development of the child’s construct systems. Kelly (1955/1991a) defined the sociality corollary as "to the extent that one person construes the construction processes of another, he/she may play a role in a social process involving the other person” (p. 66).Kelly is emphasizing how a social role develops when one person is actively trying to understand the construing of the other. The developing self-theory of the child is dependent on these social roles. Salmon (1970) sums it up in stating that "since relationships with others are central to the concept of personality, and since expanding role playing abilities define the ever-widening limits of the child’s interpersonal relationships, the concept of sociality seems a key one in the psychology of personality development” (Salmon, p. 206).In the role relationship, the child and the mother are continuously attempting to construe each other's construction processes. Each is "getting to know the other" and this is driven by the need to satisfy the infant's basic needs: safety, security, being soothed, and being seen (Siegel, 2013, p. 34).

\section{How Children Construe their First Interpersonal Relationships Influences how They Approach and Respond to Future Relationships}

Through repeated behavior infants begin to impose meaning on repeated patterns of events by making simple discriminations of similarity and difference (Mancuso, 2003).This repeated pattern of discriminations yields bipolar constructs of increasing complexity. Consequently, "by use of such complex, elaborated constructs,” infants“ can make inferences about novel objects and events so that they can begin to anticipate the outcomes of their responses to those objects and events” (Mancuso, 2003, p.276). For instance, infants come to view new acquaintances according to previously formed bipolar constructions of self-other. When in secure relationships, a baby's constructions of self-other allow for new and different perspectives or meanings. Events usually confirm the child's predictions and encourage further exploration. The child also discovers that meaning-making is a fluid 
process with "the same events (confirming) different constructions and different or even incompatible, events may appear to validate the same construction” (Kelly, 1970, p. 3).

These early interpersonal relationships also impact the structure of a child's construct system. Kelly (1955/1991a) distinguished preemptive and constellatory constructs from propositional constructs. Propositional construing for a child in a secure relationship is basically "as if" in form, allowing the child the greatest chance to develop a self-theory along the lines of "I am myself as if among other things.”While these early interpersonal relationships influence the development of the child's self-theory, self-theories also develop under other conditions. A preemptive self-construct for a child in an insecure relationship may be, “If I am unworthy, I am nothing but unworthy.” By contrast, a constellatory construing of self could be, "If I am quiet, then I am able to be safe because grown-ups won’t pick on me.’These structural processes guide the choices or responses of the child in forming and developing relationships with others.

During John’s infancy, interpersonal relationships did not lead to his basic needs being met. Relationships with others were not secure and John was unable to form useful discriminations of similarity or difference that permitted him to positively anticipate new relationships. John engaged in preemptive self-construing, which didn’t resolve into propositional construing. He spoke of himself as "bad,” which he concluded must be so because he was always in trouble for doing "bad things.” His reactions to events and his behavior toward others made it very difficult for others to construe him positively. His behavior validated his self-theory that he was “no good.”His attachment difficulties affected (a) how John understands himself, (b) the quality of his self-other constructions, and (c) how he is able to relate to others.

The influence of social and cultural beliefs and norms helps to provide and maintain the child's sense of self, leading the child to develop a number of roles in different 
contexts—each "with its own self history, anticipatory nature and validational history" (Butler\& Green, 1998, p. 51). Children are “defined and define (themselves) in relation to members of the family and other figures in (their) lives in a dialectic of social and personal processes” (Proctor, 2007, p. 191).

The often preverbal constructs central to self that children use to make sense of themselves (Viney, 1996) are called core role constructs (Kelly, 1955/1991a). Kelly (1955/ 1991a) also identified peripheral constructs as "those which can be altered without serious modification of core structure” (Kelly, 1955/1991a, p. 356). Core role constructs are formed in infancy and develop as infants repeatedly test them out in family relationships and novel contexts. When infants' basic needs are not met appropriately, they develop negative core constructs of self and their relationships with others. They interpret other people's views of them through their own self-view, thus the view of others becomes primary evidence of how they understand themselves. For example, "construing the expectations of parents informs a child about his/her own identity as either someone who is fundamentally lovable or as someone worthy only of neglect” (Farnsworth \& Sewell, 2012, p. 252). The inclusion of the child along with family members can lead to effective therapy (Proctor, 2007).

Holding negative self-constructs formed through his understanding of his parent's construing of him, John mistrusts others and engages in behaviors that confirm his current negative core constructs.

\section{Psychological Problems Develop When Infants and Parents Misunderstand Each Other and Fail to Form a Role Relationship}

Children who do not receive sensitive, responsive, nurturing care develop constructions of self-other relationships that can be described as attachment insecurities. Such infants construe the relationship as insecure, experiencing their mothers' responses to 
their needs as inconsistent, unavailable or hostile. They begin to elaborate a notion of self that is based on expectations likely to be invalidated or construed as irrelevant. These babies and their mothers are not in role relationships; they are unable to construe each other's construction processes. Consequently, the babies’ basic needs are not satisfied appropriately. Because the most fundamental of emotional needs - namely to be safe and secure—are not met, such children develop more severe attachment difficulties. Attachment insecurities strongly influence how children differentiate between constructions of self and not self (Mancuso, 2003). Insecure children experience difficulties in anticipating the outcomes of their personal actions, as it is difficult for them to infer how others will respond to their behavior. It is also difficult for them to construe others, including themselves as persons (Mancuso \& Ceely, 1980).Recent research into children’s construing of themselves as persons has led to the finding that insecure children experience specific difficulties in (a) construing a positive and stable self-image and (b) their representations of relationships (Procaccia, Veronese,\& Castiglioni, 2014).

\section{Conceptualization of Children's Psychological Problems is centered on Constructive}

\section{Alternativism}

Personal construct psychology has been described as a "psychology of the human quest. It does not say what has or will be found, but proposes rather how we might go about looking for it” (Kelly, 1970, p.1).Adopting the core philosophical assumption of personal construct psychology, constructive alternativism, the therapist conceptualizes the psychological problem by assuming that no one has direct access to the truth and that people differ in their constructions of events and experiences. Psychological problems in childcentered personal construct psychotherapy are viewed as one of a number of paths of inquiry into discovering more about how children construe or understand self in relationship to others. For the therapist, the children's constructions of the psychological problem are not 
isolated experiences, but are representative of how they make sense of their world, a view also held by other play therapy approaches.

Kelly (1955/1991b) maintained that psychotherapists need to set out to understand children's personal meaning structures and how they are related to the children's broader construct systems. Through a process of evaluation a therapist subsumes a child's construct system, allowing an understanding of how the child experiences self and world (Kelly, 1955/1991b).Subsuming the child's construct system involves working with what the child provides both verbally and nonverbally, as psychological problems in children are communicated by both verbal and nonverbal means. Kelly (1955/1991a) also identified preverbal constructs, which begin in infancy when there is little linguistic construing and continue into the present as feelings because no word symbols were ever developed for these constructs.

As a function of how children anticipate events, their construction systems change (Kelly, 1955/1991a).These changes reflect their unique meaning-making processes. They may involve changes in subordinate constructs with little effect on the children's construing of self-other, or more substantial changes in their core constructs. More often than not conceptualization of the psychological problems of children focus on their sense of identity and the reality of the world in which they live (Hardison,\& Neimeyer, 2012), on their core constructs of self-other. And while peripheral constructs can be altered without children changing their understandings of themselves, their therapists understand that core constructs are idiosyncratic and harder to change. Therapists avoid invalidating current self-other constructions before alternative self-other constructions are available.

\section{Behavior Carries its Own Unique Sense for Children and is Central to Understanding Their Construing of Self-Other}


In personal construct psychology, children are individuals for whom every situation has a unique personal meaning and their behavior can be understood only in terms of the constructions they place on them (Kelly, 1955/1991a).Changes in behaviors are a function of their own endeavors to (a) grasp the nature of the world, (b) understand themselves and others, and (c) discover new possibilities for the future (Salmon, 1970, p. 203). Children's behavior is affected by the comparisons they make between their and others' behavior (Bannister \& Agnew, 1977).How they construe their behavior towards others is derived from the roles they play with other people, the common understandings they share with them, and the "agreed network of implications" shared with others in important personal relationships (O’Reilly, 1977, p. 214).

Behavior is viewed as experimental, not reactive, revealing much about how children construe self-other. Kelly (1955/1991b) did not provide a therapeutic approach, but rather advocated a system of psychological disorder based on diagnostic dimensions of construction and transition, what he called "transitive diagnosis.” The psychological problem is conceptualized according to behaviors and the meanings children have.By advocating for a system of psychological disorder based on diagnostic dimensions of construction and transition (Kelly, 1955/1991b), the therapist avoids an approach built on psychopathology and conceptualizing psychological disorders. Rather the therapist sets out to capture an understanding of children's experience, their construing processes, and form hypotheses based on these understandings.

Using transitive diagnosis, John's hostile responses can be diagnosed as a desperate attempt by him to "protect" self. Early in life he was not protected by his parents; experiences of trust were lacking, leaving John feeling “ under attack” by others. The therapist considered where in the experience cycle John feels stuck, and what core constructs are under threat. 
The experience cycle (Kelly, 1955/1991a) describes change process and consists of five phases. It begins with the phase of anticipation and then moves to the phase where the child is open to experimenting with a new event or experience. The third phase takes place when the child encounters the new event followed by the fourth phase in which the experience is construed as either confirming or disconfirming of the predicted outcome. The fifth phase, the stage of constructive revision, occurs when the child takes a fresh view at long-held views of themselves, self-theories.

The therapist hypothesized that if John is assisted in understanding his behaviors and those of others, rather than reacting to others and then negatively reacting to himself, greater opportunities would be created for John to experiment with behavioral changes. This is what occurred as John's anxiety decreased and his trust in the therapy increased. He began to ask the therapist for her understandings of why others were not getting along with him.

For the child-centered personal construct therapist, psychological problems result when children's constructs are impermeable, resulting in behavioral positions which they are unable or unwilling to test or change.

For example, John understood himself as “bad” and nothing but “bad.”Children’s constructions of behaviors are also used by their therapists to determine the stage of the change cycle they are in; this identifies which core constructs are threatened and difficult to change. Until John was able to experience some security at home and in the therapy relationship, he was unable to revise this core construing that he must be "bad" because, as he understood it, significant people like his mother related to him as a "bad boy."

The Establishment of the Therapeutic Relationship is Central to the Practice of ChildCentered Personal Construct Psychotherapy 
It is while working within the therapeutic relationship that child-centered personal construct therapists(a) mobilize and implement techniques to understand and engage with children's constructions of self-other, and (b) communicate their own construing and reconstruing of client difficulties. These techniques or strategies are also used to assist therapists to reflect to their child clients the changes they are making in their constructions of self-other. Kelly (1969b) provided the following account of personal construct psychotherapy and the use of techniques and strategies:

Personal construct psychotherapy is a way of getting on with the human enterprise and it may embody and mobilize all the techniques for doing this that man has yet devised. Certainly there is no one psychotherapeutic technique and certainly no one kind of interpersonal compatibility between psychotherapist and client. The techniques employed are the techniques for living and the task of the skillful psychotherapist is the proper orchestration of all of these varieties of techniques. Hence one may find a personal construct psychotherapist employing a huge variety of procedures-not helterskelter, but always as part of a plan for helping himself and his client get on with the job of human exploration and checking out the appropriateness of the constructions they have devised for placing upon the world around them. (pp. 221-222)

Establishing the therapeutic relationship, leads therapists working within child-centered personal construct psychotherapy to emphasize the inherent individuality of a here-and-now process in which they work "with (the child) at this moment of emergent understanding of the problem before them” (R. A. Neimeyer, 2009, p. 59). They are actively attempting to understand the problem and their clients' behavior reflexively, in the same manner they understand their own construing. Establishing the therapeutic relationship will also involve the therapist adopting a credulous approach, an attitude of acceptance (Kelly, 1955/1991a). 
For clients like John, it is crucial that the therapist accept him and validate his capacity to make meaning. When John began therapy he was mistrustful of most people, including the therapist. In gaining John’s acceptance, the therapist was required to contain John's intense and poorly controlled negative emotions.

With no assumptions made of the child's meaning-making of self-other, the therapist attempts to see things from the child's perspective and to accept and trust the validity of that perspective. Trusting that perspective, requires the therapist to continually engage in a process of confirming an understanding of the child's meanings. Another concept proposed by Kelly (1969a), the “invitational mood,” involves a willingness by the therapist to take on other points of view to assist understandings within the therapeutic dyad. This may involve the use of metaphors by the therapist and the child, a concept that goes beyond one meaning and can unite the meanings of separate things by becoming the "lens" for viewing the other (Buzzecoli, Carattoni, \& Favaro, 2012).Metaphors help children translate their experiences and understanding of the outside world into personal constructions (Buzzecoli et al, 2012).During the process of developing a therapeutic relationship with children, therapists also adopt the role of inquirer rather than expert (Dalton \& Dunnett, 2005) and promote the technique of hypothetical and provisional ways of thinking (Truneckova \& Viney, 2012). They are communicating to children that, as clients, they are the experts who have the inner resources and capabilities to accomplish change. Child clients are actively encouraged to test what they think they know and to keep asking questions and inquiring to learn more.

While establishing the therapeutic relationship, therapists focus not on the problem which led to the referral, but on the whole child (Agnew, 1985).Therapists begin by attempting to understand their child clients' construction systems, or how their clients makes sense of self-other and of events-a technique involving continuous anticipatory effort on the part of children and their therapists (Salmon, 1970) to make sense of self-other. 
While forming a therapeutic relationship with John, it was necessary for the therapist to relate to the whole child and not John's violent and hostile acts.

During the second year of therapy, John's foster mother went on a 10-day holiday and John was placed in respite care. During this time John found it very difficult to regulate his emotions. He would arrive using sexualized swearing and threatening to physically hurt others. His construing of this event appeared to be: "I continue to be hurt because I am bad and the evidence of my badness is that I continue to be hurt by being left behind.” At school he was exposing himself to other children in his class and in the playground. At this time there were three incidents where he threatened to self -harm using drawing pins, scissors, and a stapler. By focusing on the whole child, the therapist saw John's behaviors as representations of the way he construes his world of relationships. When the therapist was able to reduce his distress, John became very remorseful saying “I’m very angry because you don't let me do what I want/ I’m angry because things never are right they are wrong/ I make people do things they don't want and that could hurt them.”

\section{Within the Therapeutic Relationship the Psychological Problems of Children are the \\ Events and Experiences to be Reconstrued before Core Construing}

The therapeutic relationship is also built on therapists validating children's understandings and accepting their meaning making capacities. Research has demonstrated that children are more likely to reconstruct their self-constructions if the therapist begins by validating the children's construing or meaning-making of themselves while invalidating (a) the children's unhelpful beliefs and attitudes of the trauma (abuse) and (b) their unhelpful beliefs and attitudes of themselves (Who I am) arising from the trauma (abuse). (Carter, \&Viney, 2013).

Therapists set out to increase the permeability of their child clients' construing to bring about changes and revisions in their meaning-making of events and experiences. 
According to Kelly, "a construct is permeable if it will admit to its range of convenience new elements which are not yet construed within its framework” (Kelly, 1955/1991a, p. 56).Permeability of the construct system enables the child to think "tightly" or "loosely" about relationship meanings.

John needed to loosen his understandings of himself in relationships. When he played “getting even” games in play therapy, the therapist provided other ways in which the various hero figures could respond to outside forces. During the course of play therapy, John acted out these attempts to loosen his construing by building traps to catch "bad guys.”These traps were increasingly followed by warnings and exit plans enabling the protagonist toy to avoid annihilation. John’s construing about "getting even” was loosening and he was entertaining other narratives. His use of toys and his play were communicating changes in construing as his behavioral responses outside therapy became less violent.

Changing the events and experiences requires child-centered personal construct therapists to help children discover and experience submerged constructions of self-other. Child clients have often not articulated and have unexplored contrasting views of problematic behaviors/feelings (Agnew, 1985) and the psychological problems remain because alternative courses of action are unavailable.

So for angry, hostile John, the submerged constructions of not feeling angry and hostile held little meaning for him. The therapist actively encouraged John to explore and experiment with the contrasting poles of his constructions of self-other by reflecting on what might be the contrasting experiences. These submerged constructions of self-other were not understood by him until he began to talk about his sisters and explore his memories of these relationships in play. He was able to begin to reflect on his feelings toward his sisters. This led to exploring his capacity to care and empathize. It also revealed his submerged constructions, which contrasted with his current ruthless dismissal of the hurt feelings of others at home and school. According to John, he loved and cared for his sisters, believing 
he protected them from harm. By articulating these submerged constructions, John was able to create an understanding of self-other beyond his current understandings.

\section{As Children encounter their World Experientially, Therapeutic Change will often Occur Experientially}

Experimental constructions involve cognitive, emotional and behavioral meaningmaking. Emotional experiences are part of children's construction of experience, serving as attempts to understand and anticipate experience. Therapists are attentive to the different means and idiosyncratic ways children express themselves (Ravenette, 1999).As Ravenette (1999, p. 197) reminds therapists, words can be merely verbal markers and not necessarily the constructs themselves. Kelly (1955/1991a) saw emotions as experiential transitional states and he identified four experiential transitional states important when working with psychological problems: anxiety, guilt, threat, and hostility. The therapist is cognizant that children experience anxiety when they find it difficult to understand or predict events. It is a precondition for change, a trigger for children to be supported in making revisions in their construction system, to reduce the potency of the psychological problem. Another trigger is when children experience guilt -the experience of self and behaviors not in keeping with one’s constructions of self. Guilt provides an opportunity for therapists to bring about change.

John is anxious when he wants something positive to happen and he is very much on “a knife edge," vacillating between whether he should follow through and achieve something or whether he should not try and just throw things in the air and rage against the world. The transitive diagnosis at this stage sees John as able to reduce his anxiety and his feelings of guilt by providing John with psychological space to encourage him to persevere. The medium for creating this emotional experience is the play therapy supported by verbal construing from the therapist. 
Children experience threat when they foresee that events confronting them are going to lead to considerable change in how they construe themselves and their core constructs. Expression of feelings of threat provides another tool in the therapist's conceptualization of the child's psychological problem.

John felt threatened when he left a known context such as home or his classroom. For 2-3 years, he refused to participate in sleep-overs or school excursions. The transitive diagnosis suggests that leaving a secure place brings back fears of "being abandoned" for John.

When the child fails to make changes to core construing, to revise the invalidated constructions, the child often experiences hostility:"Hostility (by the child) is the continued effort to extort valid evidence in favor of a type of social prediction which has already proved itself a failure” (Kelly, 1955/1991a, p. 375).Instead of revising the invalidated construction, a psychological problem develops because the hostile child is exhorting evidence to prove being right all along. An example of John's hostile repetitive play over two years demonstrates how he was trying to extort evidence despite invalidation.

He tied string around each of two soft puppets and asked the therapist to hold the end of the string while he held the other end. The puppets were swung aggressively against each other with John often reminding the therapist that she was "not doing it right” because, in his view, she was not fighting back in the proper way. The therapist felt powerless to defend what she was doing in the face of the increased intensity in the rage and revenge he was enacting against the soft puppets and the apparent sadistic engagement he was experiencing doing this. The therapist started to put time limits on this play to regulate his emotional experience and to allow loosening in his self-construing. Later John was able to acknowledge similar feelings as ones he experienced when his father was hitting him. As John's belief in himself and in his ability to make-meaning were validated in therapy, the hostile potency of the play decreases when other alternative self-other constructions became 
more available for him. Instead of John making the puppets crush or bash each other, he began to construe a narrative for each of the toys involving the relationship of the toys to each other. Rather than needing to defend against feeling powerless and helpless, more positive beliefs and attitudes about self-other were now available for John. He does not have to attack others to stop being hurt by others.

\section{Play Therapy Facilitates the Communication of Experiential Constructions}

Therapeutic change often occurs experientially rather than cognitively as children encounter their world experientially. Experiential expression often comes with no concurrent associated language. Play therapy assists in facilitating the communication of emotional experience and the verbal articulation of preverbal construing.

Child-centered personal construct therapists help children to translate their experiences using play therapy. This may involve thoughts, sensations, feelings, and memories of self-other. This process of translation requires some understanding by therapists of their child clients' individual learning paces and styles, and of their ability to generalize about and reconstrue learned material. It also requires therapists to focus on the functional value or meaning of children's behavior, as behavior is understood as an enactment in order to find out; that is, it is an experiment representing an elaborative choice (Agnew, 1985). As enacted behavior is translated into verbal language, therapists begin to assist children to develop coherent narratives of the role their emotional states play in life events. The development of the narrative requires therapists to actively encourage and develop capacities of reflection to assist making the link between emotional states and life events. The self-narrative helps children to become self-reflective. It also allows them to reflect on how they can separate a part of themselves from their problems and consider taking on the perspectives of others. Reflection becomes an interpretative act, a means whereby both children and therapists can construe the way children are (Butler,\& Green, 
1998, 2007).Insight into the patterns and past relationship dynamics is often not available for children, but by providing interpersonal emotional regulation children are better able to develop the capacity to reflect on behavioral responses and anticipations.

With his intellectual disability and undeveloped emotional literacy, reflection is difficult for clients like John. He finds it difficult linking thoughts and feelings to his reactions. He needs to feel understood experientially before he can begin to reflect on his constructions of selfother.

As therapists subsume their child clients’ construing of self-other, they are constantly asking themselves what private meanings of their child clients are in play. The transitive diagnosis becomes the mechanism by which therapists continue posing hypotheses in relation to the evolution of their clients' therapeutic play. These hypotheses are tested through the therapist's construing of the child's behaviors.

Instead of construing John's constructions of self-other based on what the therapist believes is taking place, the therapist construes how John is experiencing/construing self-other through his behaviors.

In the process of understanding the child, the activities and toys are like the child's words, and play is the child’s language (Landreth, Ray,\& Bratton, 2009).The child uses the play activities to directly or symbolically act out feelings, thoughts and experiences that are not able to be meaningfully expressed through words (Axline, 1969).All play in childcentered personal construct psychotherapy is treated as an integral part of a larger picture. What may seem disconnected in the play process is integrated by the therapist into a larger picture of meanings of self-other. Therapists approach children's play as a process through which children translate their inner emotionality into metaphorical form. As children construe the meanings of self-other constructions that originated in infancy, the emotional 
behaviors or responses that occur to inform the therapist's understanding of how these children view relationships. Play therapy provides a context for understanding the metaphorical meanings behind how children construe relationships.

\section{A Collaborative understanding between Personal Construct Psychotherapy and}

\section{Attachment Theory Informed Practice}

Personal construct psychotherapy and attachment theory recognize that children's sense of self and others, their expectations and behaviors, develop from the intimate relationship between baby and caregiver. Therapeutically both approaches believe it is more effective to take on new positive constructions or representations than to ameliorate the negative constructions or representations that continue to fashion constructions or internalizations of self-other.

For both approaches the primary focus of therapeutic practice is to work within the therapeutic relationship fostering in children the feeling they are worthy of care and to challenge previous constructions or models that suggest otherwise. However, it is personal construct psychotherapy that provides the therapeutic vehicle for bringing about psychological change. It provides processes of inquiry "designed to answer the "Why? question rather than 'how to do it' procedures for treating particular clinical problems” (Butler, \& Green, 2007, p. 212). Based on the assumption there are always potentially alternative ways of making sense of each other, ourselves and our worlds, personal construct psychotherapy provides the tools and strategies to invalidate constructs and to reconstrue beliefs of self in relation to others.

\section{The Clinical Implications of Child-Centered Personal Construct Psychotherapy}


Working from the central position that changes in a child's construing are the result of the meanings the child imposes on occurring events and experiences, child-centered personal construct psychotherapy sits comfortably within a personal construct psychotherapy approach and more broadly a constructivist orientation. Psychological problems are conceptualized as the constructed meanings of the child that are no longer helpful to the child. Change happens when the child's ways of creating meaning are explored and potentially revised. It provides a psychological intervention for children with complex psychological needs, with significant cognitive and emotional disabilities. It is an approach that respects the individuality of the child and validates the child's capacity to make meaning.

\section{Conclusion}

Child-centered personal construct psychotherapy is constructed around the child. It is focused primarily on the child's unique personal meanings. In our approach the child defines and directs the therapy. The role of the therapist becomes evaluating the child's construct system and the child's construing of self-other. Child-centered personal construct psychotherapy draws on the process of play therapy to allow children to therapeutically explore their senses of self and others. The therapeutic relationship with the child is of primary importance to the processes of therapeutic change. It is within this relationship that the child and the therapist co-create more helpful working models of self and other and validate the development of interpersonal relationships essential for the developing child. 


\section{References}

Agnew, J. (1985). Childhood disorders or the venture of children. In E. Button (Ed.), Personal construct theory and mental health: Theory, research and practice (pp. 224-245). London,UK: Croom Helm.

Ainsworth, M. D. S., Blehar, M. C., Waters, E., \& Wall, S. (1978). Patterns of attachment: A psychological study of the strange situation. Hillsdale, NJ: Erlbaum.

Axline, V. (1969). Play Therapy. New York, NY: Ballantine Books.

Bannister, D., \& Agnew, J. (1977). The child’s construing of self. In A.W. Landfield (Ed.), Nebraska symposium on motivation 1976 (pp. 99-125). Lincoln, NE: University of Nebraska Press.

Bannister, D., \& Fransella, F. (1986). Inquiring man: The psychology of personal constructs (3rd ed). London, UK: Routledge. doi/10.4324/9780203405321

Bowlby, J. (1973). Attachment and loss, Vol. II: Separation, anxiety and anger. New York, NY: Basic Books. (Original work published 1975)

Bowlby, J. (1980). Attachment and loss, Vol. III: Loss, sadness and depression. New York, NY: Basic Books.

Bowlby, J. (1982). Attachment and loss, Vol. I: Attachment. London, UK: Hogarth Press. (Original work published 1969)

Bowlby, J. (1998). A secure base: Clinical applications of attachment theory. London, UK: Routledge. (Original work published 1988).

Butler, R.J., \& Green, D. (1998). The child within: The exploration of personal construct theory with young people. Oxford, UK: Butterworth-Heinemann. 
Butler, R., J. \& Green, D. (2007). The child within: Taking the young person's perspective by applying personal construct psychology(2nd ed). Chichester, UK: John Wiley.

Buzzecoli, K., Carattoni, S., \& Favaro, A. (2012). The role of the metaphor in therapeutic conversation. In M. Giliberto, C. Dell’Aversano, \& F. Velicogna (Eds.), PCP and constructivism: Ways of working, learning and living. Proceedings of the XVIIIth International congress on personal construct psychology (pp. 236-251). Firenze, Italy: Libriliberi.

Carter, C., \&Viney, L. L. (2013). Exploring deep meanings to facilitate change: Using personal construct therapy-the quiet achiever. The Australian Journal of Counselling Psychology, 13,3-7.

Chiari, G. (2013). Emotion in personal construct theory: A controversial question. Journal of Constructivist Psychology, 26, 249-261. doi/10.1080/10720537.2013.812853

Dalton, P., \& Dunnett, G. (2005). A psychology for living: personal construct theory for professionals and clients (2nd ed.). London, UK: Whurr.

Farnsworth, J., \& Sewell, K. W. (2012). Fearing the emotional self. Journal of Constructivist Psychology, 25, 251-268. doi/10.1080/10720537.2012.679131

Hardison, H. G., \& Neimeyer, R. A. (2012). Assessment of personal constructs: Features and functions of constructivist techniques. In P. Caputi, Viney, L. L., B.M. Walker, \& N. Crittenden (Eds.), Personal construct methodology (pp. 3-51). Chichester, UK: Wiley-Blackwell. doi.org/10.1002/9781119953616.ch1.

Kelly, G. A. (1969a). The language of hypothesis: Man’s psychological instrument. In B. Maher (Ed.), Clinical psychology and personality: The selected papers of George Kelly (pp. 147-162). New York, NY: John Wiley. 
Kelly, G. A. (1969b). The psychotherapeutic relationship. In B. Maher (Ed.), Clinical psychology and personality: The selected papers of George Kelly (pp. 216-223). New York, NY: John Wiley.

Kelly, G. A. (1969c). Hostility (1957). In B. Maher (Ed.), Clinical psychology and personality: The selected papers of George Kelly (pp. 267-280). New York, NY: John Wiley.

Kelly, G. A. (1970). A brief introduction to personal construct theory. In D. Bannister (Ed.), Perspectives in personal construct theory (pp. 1-29). London, UK: Academic Press. (Original work published 1966). doi.org/10.1002/0470013310.ch1

Kelly, G. A. (1991a). The psychology of personal constructs. Vol. 1. A theory of personality. London, UK: Routledge. (Original work published 1955). doi/10.4324/9780203405970

Kelly, G. A. (1991b). The psychology of personal constructs. Vol. 2. Clinical diagnosis and psychotherapy. London, UK: Routledge. (Original work published 1955). doi/10.4324/97800203405987

Landreth, G. L., Ray, D. C., \& Bratton, S. C. (2009). Play therapy in elementary schools. Psychology in the Schools, 46(3), 281-289. doi/10.1002/pits.20374.

Main, M., \& Solomon, J. (1986). A discovery of a new, insecure disorganised/disorientated attachment pattern. In T. B. Brazelton \& M. Yogman (Eds.), Affective development in infancy (pp. 95-124). Norwood, NJ: Ablex.

Mancuso, J. C. (2003). Children's development of personal construct. In F. Fransella (Ed.), International handbook of personal construct psychology (pp. 275-282), Chichester, UK:Wiley. doi: org/10.1002/0470013370.ch27. 
Mancuso, J. C., \& Ceely, S. G. (1980). The self as memory processing. Cognitive Therapy and Research,4, 1-25.

Neimeyer, R. A. (2009). Constructivist psychotherapy: Distinctive features. New York, NY: Routledge.doi.org/10.1037/10517-105.

Neimeyer, R. A., \& Neimeyer, G. J. (1987). Personal construct therapy casebook. New York, NY: Springer Publishing Company.

O’Reilly, J. (1977). The interplay between mothers and their children: A construct theory viewpoint. In D. Bannister (Ed.), New perspectives in personal construct theory (pp. 195-219). London, UK: Academic Press.

Procaccia, R., Veronese, G., \& Castiglioni, M. (2014). Self-characterization and attachment: A creative method of investigating children's construing. Journal of Constructivist Psychology,27, 174-193. doi:10.1080/10720537.2014.904901.

Proctor, H. (2007). Construing within the family. In R. J. Butler \& D. Green (Eds.), The child within: Taking the young person's perspective by applying personal construct psychology (2nd ed., pp. 190-206). Chichester, UK: John Wiley.

Raskin, J. D. (2013). Thinking, feeling, and Being Human. Journal of Constructivist Psychology, 26, 181-186. doi:10.1080/10720537.2013.787323.

Ravenette, T. (1999). Personal construct theory in educational psychology: A practitioner's view. London, UK: Whurr.

Salmon, P. (1970). A psychology of personal growth. In D. Bannister (Ed.), Perspectives in personal construct theory (pp. 197-221), London, UK: Academic Press. 
Sassaroli, S., \& Lorenzini, R. (1992). Attachment as an informative relationship. International Journal of Personal Construct Psychology,5, 239-247. doi: 10.1080/08936039208404314.

Siegel, D. J. (2013). Brainstorm: The power and purpose of the teenage brain. New York, NY: Jeremy P. Tarcher/Penguin.

Truneckova, D., \& Viney, L. L. (2012). Personal construct psychology model of school counselling delivery. British Journal of Guidance and Counselling, 1-18. doi/10.1080/03069885.2012.718739

Viney, L. L. (1996). Personal construct therapy: A handbook. Norwood, NJ: Ablex Publishing Corporation. 